\title{
The Present and Future of Kuwaiti-Iranian Relations and Their Influence on the Security of the Arabian Gulf
}

\author{
Khaled Abdulaziz Alsalloum $^{1} \&$ Mohamed Salman Tayie $^{1}$ \\ ${ }^{1}$ Faculty of Economics and Political Science, Cairo University \\ Correspondence: Khaled Abdulaziz Alsalloum. E-mail: khaledalsalloum@hotmail.com
}

Received: October 11, 2017

Accepted: November 1, 2017

Online Published: December 27, 2017

doi:10.5539/ass.v14n1p102

URL: https://doi.org/10.5539/ass.v14n1p102

\begin{abstract}
Objective: The objective is to study the present and future of Kuwaiti-Iranian relations through the determinants of the geographical, social, economic and political relationship and the reflection of that relation on the security of the Gulf. The study also examines the future of Gulf security in light of the Kuwaiti-Iranian relations.

Method: The study used the approach of the national interest because it is linked to the theory of power, according to Hans Morgenthau, since power is the goal of the foreign policy maker, a major objective of the state in its external relations. Where the political interactions of Kuwait with the Gulf States and Iran is considered in accordance with its national interest.

Results: The study concluded that the Kuwaiti-Iranian relations were positive at most stages and that security is one of the most important problems for small countries, but it is capable of playing a role in regional security. The future of Gulf security is linked to the relations of Gulf countries and Iran with major countries and for Kuwait specifically in its relationship with the United States of America and Western Countries through the security and military agreements.

Conclusion: The study shows that the State of Kuwait as a small country played a major role through its political and geographical determinants in resolving regional disputes and conflicts.
\end{abstract}

Keywords: Determinants, Iran, Kuwait, Regional Security

\section{Introduction}

The study discusses the present and future of the Kuwaiti-Iranian relations and their influence on the security of the Arabian Gulf. The study deals with the role of Kuwait in working to resolve disputes and conflicts between the Gulf countries and an example of those disputes is the Saudi Arabia and Qatar crisis in 2014, and the crisis of the United Arab Emirates in 2012, in addition to Kuwait's quest for the role of mediator in the Gulf-Iran conflicts, the most important of which is the Iranian-Gulf dispute and its role in convergence of views and work to solve them as the strategic geographical location of the State of Kuwait distinguished its role within the Gulf system, in addition to the policy of neutrality and balance adopted by Kuwait in its relations with the countries of the Gulf region, especially since it is located between countries that consider large countries such as Saudi Arabia, Iraq and Iran compared to a small country like Kuwait which is located in the same region. There is no doubt that the Kuwaiti-Iranian relations are affected by the development of Kuwait in relation to countries of Gulf Cooperation Council, and also affected by the general framework governing those relations, which witnessed many disputes and crises. Despite the improvement in Kuwaiti-Iranian relations, Kuwait has not emerged from the Gulf situation on key issues such as border disputes (the three UAE islands) and some other disputes. This study will help researchers understand the historical nature of Kuwaiti-Iranian relations which are extended from 2003-2015 in addition to the future relations that will be addressed through the most important determinants of the relationship between the two countries, political and economic, geographical and social-demographic, which lead to create a kind of understanding and mutual trust in some Gulf and regional issues, The study will also discuss the future of Gulf security and the future of Kuwaiti-Iranian relations.

\section{The Problem of the Study}

In view of the policy of the State of Kuwait in its regional environment in the past and present, we believe that the State of Kuwait has taken a policy of strategic hedging and balance in its relations with Iran on the one hand and its relationship with the GCC countries on the other hand taking into account not to deviate from the policy in some main issues that gather the GCC countries, so the study seeks to answer the main question which is to what extent the nature of Kuwait - Iran relations, whether it is a conflict or cooperation, on the security of the Persian Gulf in the future?

This study deals with the present and future of Kuwaiti-Iranian relations through the following points:

1. Introducing the concepts of the study. 
2. The reality of the Kuwaiti-Iranian relations.

3. Determinants of Kuwaiti-Iranian relations.

4. The future of Kuwaiti-Iranian relations.

5. Conclusion

\section{Concepts of the study}

\subsection{The concept of regional security:}

Regional security is a relatively recent term that has emerged during the period of the two world wars. It reflects the policy of a group of countries belonging to one region and seeking through their military cooperation to prevent any outside force from intervening in that region. The essence of this policy is territorial mobilization from one hand, to counter internal power on the second hand and protect the status quo on the third hand (Alawi, 2005). Regional security mediates between individual and national security and collective or international security. Another definition of the concept of security is that by linking its components, such as security and order or between security and security partnership, as some people define the term of regional security partnership as a security arrangement within an area rooted in the consensus of States to cooperate to reduce violence and promote stability and peace in the region through various types of agreements and mechanisms such as formal security treaties and international security organizations (Jones, 1998). There are developments that have led to the importance of regional security in the post-cold-war; the first is that the emergence of regional security has become an important issue for the superpowers as they possess the necessary energy for most countries of the world and the second is the outbreak of regional conflicts and wars, which lead to the threat of the world order, in addition to increased demand for regional security arrangements.

\subsection{Concept of Mini-State}

The concept of the nation state emerged after the Westphalia Convention of 1648, and the issue of discrimination between states exists. This process has gone through a number of stages, as classification has become a shift dominated by political, economic, military and technological data and there has been a so-called Mini-State, Middle State, Power State and Superpower State. The State has been addressed from two perspectives, the first being legal, which equates countries from two perspectives, the first of which is the law, which equates States in terms of their sovereignty, their right to exist, and not allowing others to interfere in their internal affairs. The second is the real one that the stats vary in terms of the capacities available to them, and therefore vary in terms of the capacities available to them and from this potential; States have the opportunity to influence the other parties (Al-Ebraheem, 1984). However, the most common definition is the size of the population, but it has not been concluded that a small or medium state considering its power in its population. Some believe that a country with a high population is not necessarily a medium or large country, in other countries, the size of a small state is relative. It depends on the influence of the superpower, or the influence of the middle state on the small state (Morgenthau, 1972), because the small state has no ability to influence the international system (Keohane 1969). Thorhalson believes that there are many factors that give the small state power in the international system, such as the degree of control over its internal affairs, its boundaries, its political and economic power, and more importantly, it is its cognitive size, that is, how these states are being seen internally and externally (Thorhallsson, 2006)

\subsection{Concept of Middle State:}

Some researchers define the middle power as a state that has greater economic and military capabilities and resources than smaller powers, and less capabilities and resources possessed by superpowers. Others have classified the middle power across a continuum, depending on the scope and depth of initiatives and issues of concern to them (Cooper, Higgott, Nossal 1993). Others rated the middle power across a continuum, depending on the scope and depth of the initiatives and issues of concern to it, while others categorize the middle power as the state that has military power, economic resources, and geographical or strategic location, that's why the superpowers demand their assistance in times of peace, although they can not win the war against the major powers. There is another criterion for determining the situation of the middle power based on non-economic criteria, including the degree of influence possessed by the middle power, which some researchers consider it as a regional power (Christie, Dewitt, 2006). Another concept of an middle state is based on its foreign behavior, its foreign policy, as using its diplomatic capabilities to serve peace, stability and international security, its tendency to pursue multilateral cooperative initiatives (Jordan, 2001). The middle state was classified as a combination of solid and soft power as it is classified as a capable state that includes elements of solid power, and focus on specific issues through which it can deal with it to a high degree and the ability to provide innovative solutions to solve dispute, the formation of coalitions linked to participation in multilateral institutions, the strengthening of it, the belief that work for the global interest is an important and supportive factor for national interests, and the credibility of a middle state in demonstrating the coherence of its external policy options based on fixed principles (Abu Laila, 2012). 


\subsection{Concept of National Interest}

The concept of national interest is a concept that emerges from the school of realism, because it is linked to the theory of power, where the concept of national interest was linked to power according to Hans Morgenthau, since power is the goal of the foreign policy maker and a key objective of the State in its external relations (Al-Kibsi, 1997). Morgenthau has classified national interests into eight main interests: primary interests, which included political and geographical unity, cultural identity and the survival of the nation against cultural excesses. The secondary interests are the interests of the citizens of the State abroad by protecting it, protecting the diplomatic immunities of their missions. The permanent interests, which are stable for a period of time but changing slowly. The changing interests are the interests that the nation determines at any time in accordance with its national interest; there is also a public and private interest. The public interests are those applied by the nation to large geographical areas and to a large number of countries, or in several fields such as economy, trade, diplomacy and international law. The private interests are determined at specific time and place, and often reflect the evolution of the logic of public interest (Tawfiq, 2012).

\section{The present of Kuwaiti-Iranian relations}

\subsection{Kuwaiti-Iranian relations at the political level}

The Kuwaiti-Iranian relations have witnessed a series of ups and downs, as well as international relations in general. The course of these relations was positive in most of its stages. The period of tension and crises between Kuwait and Iran did not exceed more than eight years which is Kuwaiti-Iraq war. Since the independence of Kuwait in 1961, the two countries' situations have been positive which led to the strengthening of relations betw een them. In 1973, Iran announced its support for the State of Kuwait in the face of the Iraqi aggression on its territory in Alsamtah incident, as well as supporting Kuwait during the Iraqi invasion in 1990, in addition to the official recognition of Kuwait in 1979 by the Islamic Revolution of Iran and the visit of the first senior Kuwaiti official from the Gulf States to Iran after the Iranian Revolution. However, after the outbreak of the Iraq-Iran war at the beginning, Kuwait committed neutrality and demanded Iraq and Iran to stop fighting and after Kuwait was attacked by Iran with rocket fire, the Kuwaiti situation changed. The Kuwaiti-Iranian relations deteriorated. The tension increased in 1985 after Kuwait accused Iran of attempting to assassinate the Amir of Kuwait and carrying out bombings by pro-Iranian people after the State of Kuwait declared its material and political support for Iraq. After the end of the Iraq-Iran war, calm returned between Iran and Kuwait until Iraq invaded Kuwait in 1990. Iran rejected the Iraqi occupation of Kuwait. In order to find a peaceful solution and stop the war, Iranian President Hashemi Rafsanjani announced in February 1991 a peace initiative through his willingness to meet Iraqi President for direct talks to stop the war, and Kuwait welcomed the Iranian initiative, but the Iraqi president rejected the initiative (Gulf Center for Iranian Studies, 2011).

With the increase of the US campaign in 2003 to bring change in Iraq, and the repercussions that will have on the region in general, and the State of Kuwait and Iran in particular, the Kuwaiti Foreign Minister Sheikh Sabah Al-Ahmad Al-Sabah visited Iran, this visit was very important, especially for the Iraqi file, and the Kuwaiti Foreign Minister said that I hope to avoid military action against Iraq (Toumi, 2014), pointing to the preference of Kuwait that the change must be from the inside of Iraq, and nothing guarantees security and stability only the cooperation of the Iraqi government with the United Nations and its inspectors, and the Kuwaiti and Iranian views coincided with that issue and both sides agreed to increase support for efforts to advance political will towards the issue of the continental shelf, and a joint committee was assigned to define the limits of the continental shelf.

In February 2006, Iranian President Mahmoud Ahmadinejad visited Kuwait and discussed bilateral relations with the Emir of Kuwait. This may have given the impression for the Iranian political leadership after the fall of the Iraqi president in 2004 with the rise of Shiite influence in Kuwait (Kuwait News Agency, 2006). In 2007, some saw that Kuwaiti-Iranian relations should improve because Kuwait and Iran are interested in the Iraqi issue, but some had another point of view as they see that there is real fear of Iranian expansion in southern Iraq because it is adjacent to the Saudi and Kuwaiti borders (Abdul Rahman, 2007).

The Kuwaiti-Iranian relations began to take the feature of tension in 2011 after the expulsion of Kuwait 3 Iranian diplomats working for the Iranian embassy in Kuwait, proved to be involved in an Iranian espionage network, and the Kuwaiti Foreign Ministry summoned its ambassador in Tehran for consultation after the Kuwaiti judiciary sentenced to execute 3 Iranians and Kuwaiti accused of involvement in the espionage network working for Iran (The Gulf Center for Iranian Studies, 2017), and this strained situation did not calm between the two countries in 2012 because of the statement of the President of the Iranian continental shelf oil company Mahmoud Zadeh, where he said that if the Iranian diplomacy will be rejected, it will continue its efforts to develop the Arash Marine Gas Field in the Gulf unilaterally, as we did in Hengam field, which is shared by Tehran with the Sultanate of Oman, unless they the State of Kuwait shall respond to the offer of joint development.

On the first conference of donors to support the humanitarian situation in Syria, which was held in Kuwait in January 2013, Kuwait invited Iran to participate in the conference. Tehran participated by the Assistant Foreign Minister for Arab and African Affairs Hussein Abdullahian (Kuwait News Agency, 2013) and provided 200 million dollars to 
support the humanitarian situation in Syria (Arab East Center for Civilizational and Strategic, 2013).

Kuwait welcomed the preliminary agreement on the Iranian nuclear program during the GCC summit held in Kuwait. In the opening speech, the Amir of Kuwait affirmed on the satisfaction of the GCC countries toward the Geneva preliminary agreement on Iran's nuclear program and hoped that it would succeed and will lead to a permanent agreement that will remove the specter of tension from the region (Al-Hayat Newspaper, 2013).

In 2014, Iranian President Hassan Rowhani called on the Emir of Kuwait to visit Tehran in a message delivered to the Amir by Assistant Foreign Minister for Arab and African Affairs Hussein Abdullahian. The Amir welcomed the invitation and called for bilateral cooperation to confront extremism and reach a political solution in the Syrian crisis (Iran Arabic Radio, 02 April 2014).

On 01 June 2014, the Amir of Kuwait visited Tehran at the invitation of the Iranian President. During the visit, he met with the Supreme Leader of the Islamic Revolution in Iran and described the Leader of the Revolution as a guide for the whole region. He said that Kuwait is ready to turn a new leaf in relations between the two countries.

The Kuwaiti Foreign Minister, speaking at the opening of the GCC meeting in Jeddah, addressed the level of foreign ministers to Iran's nuclear program as he said during his speech that we should have a close relationship with Iran (Fars News Agency, 2015).

As for the explosion of the Al-Sadiq Mosque, which took place on 26/6/2015 in Kuwait City, which resulted in a number of deaths and injuries (Kuwait News Agency, 2015), Iran condemned the terrorist attack through a letter sent by the Iranian President to the Amir of Kuwait. He expressed his condolences to the Amir of Kuwait and its government and people. A telephone call to the Iranian Foreign Minister to the Kuwaiti counterpart, through which he expressed his sympathy with the government and the Kuwaiti people. The religious authorities in Tehran also condemned the bombing and called on them to promote unity and solidarity. A delegation headed by Ayatollah Mohammad Al-Taskhiri, representative of the Iranian Revolutionary Leader, accompanied by Ayatollah Abbas, a member of the Board of Experts, presented condolences to the government and people of Kuwait.

After the nuclear agreement between Iran and the P5+1 in Vienna, the Amir of the State of Kuwait sent a cable of congratulations to the Leader of the Islamic Revolution of Iran and the Iranian President congratulated them on the historic agreement. He expressed his hope that this agreement will contribute to enhance security and stability in the region (Fars News Agency, 2015). The first visit of The Iranian foreign ministry, after the nuclear agreement, was to the State of Kuwait to discuss the outcome of the nuclear talks and bilateral relations. The aim of the visit is to reassure the Gulf States on its nuclear agreement, as his visit to Kuwait comes as a result of good political relations between Tehran and Kuwait (Al-Alam TV, 2014)

Back to the strained relations between Kuwait and Iran, the State of Kuwait revealed an espionage network group called Al-Abdali group and the prosecution charged the accused with committing acts that would undermine the unity and territorial integrity of Kuwait, and the accusation of seeking and communicating with the Islamic Republic of Iran, and with Hezbollah to carry out hostilities against Kuwait (Kuwait News Agency, 2017), Iran expressed, through the statement of the Iranian Embassy in Kuwait, its deep dissatisfaction with the statement issued by the Public Prosecution, which put name of Tehran in the Al-Abdali group, considering that the accusation was based on vague charges. Kuwait expressed its deep regret of the Kuwaiti Foreign Ministry through an official source and refused the statement of the Iranian Embassy, in order to overcome the most basic rules and diplomatic norms, is that the expression of official states' situations and their desire to obtain any information on any issue should be through the official channels, not through the media. The foreign ministry handed over a memorandum to the Iranian ambassador explaining Kuwait's situation on the case (Al-Watan newspaper, 2015).

As a follow-up to the tension of the Kuwaiti-Iranian relations, Tehran announced through the National Iranian Oil Company that two projects were proposed to develop the extension of the Al-Durra field (Arash) to foreign companies, ignoring the Kuwaiti rejection of any development projects in the field prior to the delineation of the continental shelf, consequently, The Kuwaiti Foreign Ministry summoned the acting of Tehran Embassy at Kuwait and submitted a protest note including Kuwait's rejection of any development in the field before the demarcation of the continental shelf, which is still the subject of regional negotiations between Iran, Saudi Arabia and Kuwait (BBC, 2015).

On 24 September 2015, the stampede of pilgrims in Mina killed a number of Iranian pilgrims and wounded others. After the Iranian Minister of Culture and Islamic Guidance revealed, during a closed session in the Shura Coun cil, that the Saudi Foreign Minister refused to meet with the Iranian Foreign Minister and after the failure of the Iranian delegation to hold talks with the Saudi side to send an Iranian team to study the dimensions of the Mina incident, the Iranian Foreign Minister held talks with the Amir of Kuwait at the United Nations General Assembly, which led to Saudi Arabia's approval of the Iranian Health Minister to Saudi Arabia (Shoma News, 2015).

During the press conference held between the Kuwaiti and German foreign ministers in Kuwait, the Kuwaiti Foreign Minister stated that we are ready to start a dialogue with Iran. The GCC countries always find that there are rules for 
cooperation with neighboring Iran. We hope to start this dialogue for the security and stability of the region (Al-Alam channel, 2015).

In the context of what was mentioned in the political relations between Kuwait and Iran, we find that in its policy with Iran, the State of Kuwait has taken the principle of balance, working to resolve the controversial issues between them and bringing the issue closer to being a small state and played a positive and effective role to protect it from Iran's expansionist ambitions. In view of Iran and its policy of intervention, which is part of the religious faith and political ideology of the State of Iranian, as well as its main determinant based on expansionist ambitions and playing a prominent role in the region. Therefore, we see that the State of Kuwait and its maintenance of the level of relations with Iran may avoid it Iran's ambitions to a certain extent, and add space for maneuver away from severing relations between them.

\subsection{Kuwaiti-Iranian relations at the economic level:}

After the independence of the State of Kuwait in 1961, economic relations between Kuwait and Iran began, by establishing economic and trade relations, as Kuwait lacked of employment and expertise, and they signed agreements and economic treaties, the most important being the Transit Agreement, trade exchange between the ports of Kuwait and Al-Muhammarah, Bushehr and Bandar Abbas and the economic and trade relations between the two countries continued, but with slow growth.

In 2004, Kuwait and Iran signed a number of memorandums of understanding on economic, cultural, scientific and military cooperation, the second on electricity and water, the third on import of gas from Iran and the establishment of bilateral investment companies in oil and gas field and Kuwait welcomed the recruitment of the Iranian labor force specialized in some sectors of labor, however, some issues remain unresolved such as the transfer of drinking water and gas from Iran to Kuwait.

During the 12th meeting of the Kuwait-Iran Joint Committee held in Tehran, the head of the Trade Development Organization announced Tehran's readiness to export gas to Kuwait via a pipeline, as well as the export of sulfur and liquefied gas at reasonable prices (Arabic CNN, 2014).

On 01 June 2014, the Amir of the State of Kuwait visited Tehran at the invitation of the Iranian President and it was agreed to raise the level of economic and trade relations. This visit led to the signing of a number of agreements between the two sides in the field of air transport, customs cooperation, environmental cooperation, as well as the security agreement (Al- vefagh Online, 2014).

The Kuwaiti-Iranian relations during the year 2015 witnessed a number of mutual visits. The Minister of Economy and Financial Affairs of Iran paid a visit to the State of Kuwait at the head of an economic and commercial delegation. The official data from the Central Administration of Statistics showed that Iran ranked 14th among the importing countries for non-oil goods and derivatives and its derivatives. The volume of Kuwaiti exports in the third quarter of 2014 reached 5.3 million dinars, an increase of $1.4 \%$ in the same period of 2013 . The data revealed that the volume of Iranian exports to Kuwait in the third quarter of 2014 amounted to 22.8 million dinars (Tabank newspaper, 2014). The President of the Iranian Shura Council visited Kuwait to study the development of economic relations and discuss important developments in the region (Fars News Agency, 2014).

In conclusion OF the process of Kuwaiti-Iranian relations during the period from 2003 to 2015, we note that the relationship between the two countries was positive in most of its stages, despite the existence of some tensions, and the State of Kuwait was able to maintain its normal relations in most periods with Iran and pursued the policy of balance as a member of the Gulf Cooperation Council, which differs in its relations with Iran, and through the consideration of the historical relations of Kuwait and Iran will address in another part of the research the future of Kuwaiti-Iranian relations in the light of regional and international changes.

\section{Determinants of Kuwaiti-Iranian relations}

The Kuwaiti-Iranian relations are influenced by a combination of data and common factors that push the two countries closer to one another or lead to divergence and conflict. Relations between Kuwait and Iran can be on the path of positive development through bilateral interaction between them that is controlled by a number of determinants, including:

\subsection{Political determinant}

- The State of Kuwait has sought to make its policy consistent with its geographical position, which requires it to deal with a great deal of flexibility and balance. Robert Duchin illustrates this in his book "Alliance and Minor Powers". He pointed out that these countries are limited in their ability to defend themselves, and that they must rely primarily on another State or other institutions in order to preserve their integrity (Hilal, 1991). The State of Kuwait, when conquered by Iraq, used a large international coalition led by the United States of America, Britain, 
France, Germany, Egypt and Syria to achieve stability (Al-Majalla, 1993) and set criteria for determining the future vision of its Foreign Policy to achieve security, the most important of which are:

- Non-interference in any external conflicts, including the Arabian Gulf.

- Reforming its relations with neighboring countries, without relying on international alliances.

- Pay attention and focus on the security of Kuwait.

The policy of Iran and Kuwait coincided with most issues. The two countries have always preferred to settle their conflicts by peaceful means without any escalation or complication of these conflicts, which allows their containment and minimization of their negative repercussions and effects, as well as resorting to quiet and peaceful methods (Hamdan, 2014).

- Given the policy of Kuwait and Iran in the previous period, we find that the future of relations between them will be dominated by the intensity of political contacts at various levels.

- Based on the basic features that characterized Iran and Kuwait in their relations, it can be said that the Kuwaiti-Iranian relations are of an integrated nature, characterized by a positive character, move away from tension, tend to peace, and resolve any dispute by peaceful means.

\subsection{Economic determinant:}

The Iranian-Kuwaiti relations will be limited to a stage of cooperation in the economic field. At the 12th meeting of the Kuwait-Iran Joint Committee held in Tehran, Tehran announced readiness to export gas to Kuwait via a pipeline, as well as the export of sulfur and liquefied gas at agreed prices. Kuwait and Tehran signed a number of economic and trade agreements in the field of air transport and customs cooperation. According to official data released by the Central Administration of Statistics, Iran ranked 14th among the importing countries for non-oil goods and derivatives. In the third quarter of 2014, the amount of Kuwaiti exports reached 5.3 million dinars with an increase of $1.4 \%$ in the same period of 2013. The data revealed that the amount of Iranian exports to Kuwait in the third quarter of 2014 reached 22.8 million dinars, indicating that relations between the two countries are moving towards more cooperation in economic and trade fields, and therefore increased economic cooperation leads to increased mutual trust, which is the basis for any development in other areas (Al-Mutairi, 2004).

\subsection{Geographical determinant}

Geographical location is one of the determinants affecting relations between States; the location of the state determines its strength, in addition to its regional and international weight. It is an important factor that draws the country's foreign relations, through the Kuwaiti-Iranian relations and the impact of the geographical location. Kuwait is a small country with an area of $17,820 \mathrm{~km} \mathrm{2}$, located on the top of the Arabian Gulf, is the passage to the northeast of the Arabian Peninsula, and is a link between the island and the plains Tigris and Euphrates and the Iranian plateau behind it, which makes it acquired commercial importance (Kuwait Research and Studies Center, 2014). Kuwait as a small country located among countries which are considered in the region as a medium, competitive and influential countries, thus imposing restrictions on movement and limits the maneuver, and therefore its policy characterized by neutrality and balance, but it took a mediating role between the regional middle powers because it enjoys balanced relations among them.

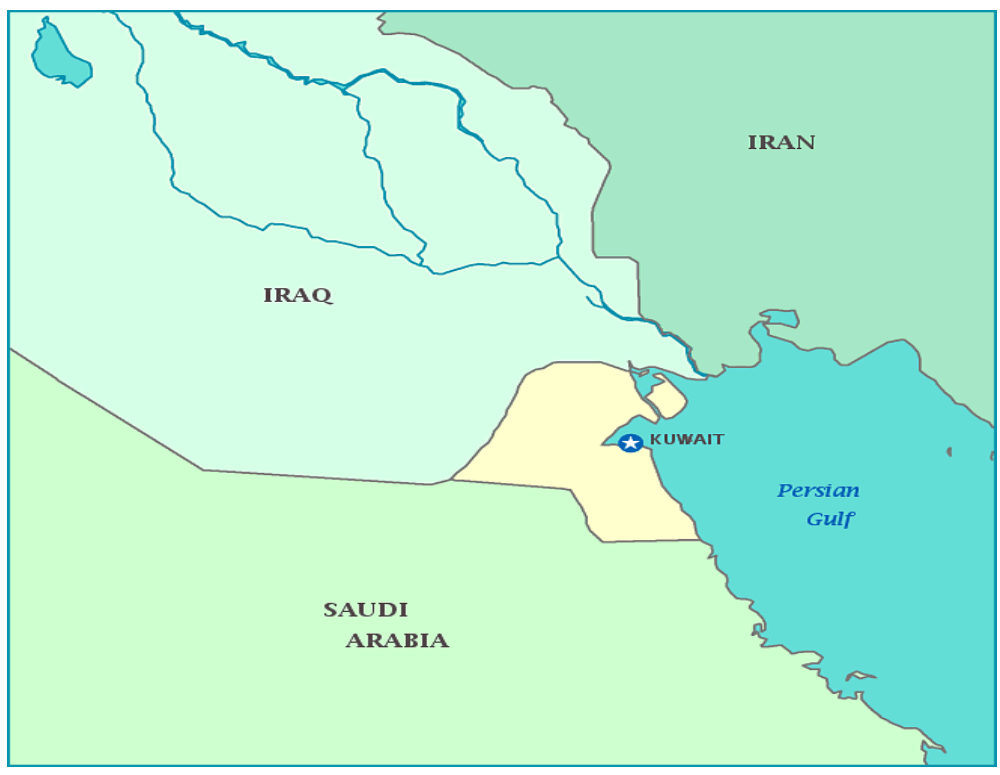

Figure 1. Map showing the geographical location of Kuwait and Iran 
Iran, which covers an area of 1,633,188 km 2, located on Central Asia, the Caspian Sea on the north, Afghanistan and Pakistan on the east, the Arabian Gulf on the south, the Gulf of Oman, and Iraq on the west. Its considered as a natural passage for international trade and oversees the most important water straits, the Strait of Hormuz (Akram, 2002).

The geopolitical status surpassed by Iran, has given it the ability to influence, and the potential to create a kind of human communication that is important in influencing the relations between the two countries. Kuwait and Iran have a common maritime border, which led to some kind of communication between them, and make Kuwait one of the closest points of convergence between the Iranian plateau, and the Arabian Peninsula, and thus Iran's geographic advantage, led to the State of Kuwait took a policy of caution, cooperation and taking a close position with Iran as a bridge between the Arab and Iranian blocs.

\subsection{Social determinant}

The demographic determinant are one of the important determinants of the Kuwaiti-Iranian relations, and as a result of the geographical proximity that led to the formation of relations between the Kuwaiti and Iranian peoples, as well as the presence of families in Kuwait whose origins are in Iran, which led to cultural and social ties between the two countries. Shiites are considered as component of the Kuwaiti society, whether they are Arab Shiites or those who have long migrated and settled in Kuwait and became Kuwaiti citizens, and their percentage in Kuwait is estimated to be about $20 \%$ of the total population of Kuwait (Ezz Al-Arab, 2012).

The sectarian factor has greatly contributed to the rapprochement of Kuwaiti-Iranian relations, and we see many Kuwaiti citizens who belong to the Shiite community always travel between Kuwait, Iranian cities with religious reference (Qom-Mashhad) and visit the holy shrines in Iran. The Kuwaiti Shiite factor has played several roles between the two countries, but at the same time it has raised fears that it is a fertile environment for Iran that can exploit it as a pressure card if it needs it in its relations with Kuwait, especially the Shiite clerics in Kuwait, which are always their situations are always in defense of Iran and reference and its leaders (Salem, 2017).

\section{The future of Kuwaiti-Iranian relations and Gulf security}

The security issue in the Gulf is one of the main issues of concern to all the countries of the region and the major international powers in particular. This regional and global interest in security in the Gulf stems from the strategic centrality of this region and its role in securing world energy security represented by oil supply, natural gas. The issue of Gulf security, whose security was linked to the security of the world, remains one of the most difficult issues, especially given the nature of this region, which is characterized by a clear imbalance in power, increasing ambitions, multiplicity of conflicts, and the diversity of sources of internal and external threats as over modern and contemporary history, the security of the Gulf has continued to be imported from abroad, provided by the major international powers, because of the lack of self-strength or inability to reach a formula and security equation in which the countries of the region cooperate to provide security (Al Hamed, 1997).

The problem of maintaining security in the Gulf is one of the most important challenges facing the countries of the region, which sought to establish the Gulf Cooperation Council in the early 1980s to fill the gap in the security vacuum in the region after the withdrawal of British forces from the Gulf in the early seventies of the twentieth century (Jamal Zakaria) and the security challenge in the Gulf stems from imbalance of power in favor of the larger regional parties, Iran and Iraq, and the inability of the small, newly independent Gulf States to secure their own security and maintain stability in the region on their own (Peterson, 1986).

Foreign presence and foreign protection of Gulf security will continue, due to the lack of self-security and regional stability, as well as the fact that the Gulf region is one of the most important global regions providing oil and natural gas (Gresh, 2015).

The Gulf region of great geopolitical importance to the world will remain an influential player on global energy security and potentially vulnerable to potential regional crises that are primarily aimed at directing and rationalizing global energy more than anything else (Abdullah, 2014).

A new concept of Gulf security is gradually taking shape, and this will have implications for the GCC decision-maker's understanding of the changes in the Gulf security equation, especially with respect to the sources of threat, where the internal threat sources are more than or equal to or equivalent to external threats.

The relations between Kuwait and Iran have a role in determining the future of security in the Gulf region. These relations have an impact on the mutual relations between the two countries, as well as on their internal Gulf relations and foreign policies. The strengthening of security cooperation between Kuwait and Iran depends on many variables including the nature of the relationship between the United States of America and Iran, where the United States occupied a large and vital part of the Gulf security arrangements after having had a major role in the military operations to liberate the State of Kuwait, so any convergence between Kuwait - Iran, especially on the security aspect must depend on the extent of coordination between the United States and Iran. This is a matter is well aware by the State of Kuwait and puts into its policies (Almutairi, 2004). 
The increase in the volume of trade and economic exchange between Kuwait and Iran during the last period may lead to the spread of mutual trust, which is the basis for any development in the field of security cooperation.

Iran has to show its good intentions in seeking to address the first issue of the Gulf, to which the State of Kuwait attaches importance to this issue, namely, the file of the dispute over the three islands, or to refer the matter to the International Court of Justice if bilateral talks between Tehran and Abu Dhabi fail (Almutairi, 2004).

The State of Kuwait and the Gulf states believe that Tehran should abandon interfering in the internal affairs of the Gulf States and understand that citizenship encompasses all sectors of the Gulf. It must be aware that it is not responsible for Shiites and that it is not the guardian of the Shiites of the world.

Kuwait and Iran must increase cooperation and agreement to build positive relations and to overcome the causes of divergence, with the promotion of bilateral cooperation. Cooperation will not be at the expense of Kuwait's relations with the Gulf countries, self-reliance and mutual interests. This will contribute to the common good of both parties and provides alternative protection for external international alliances.

In order to enhance Gulf security, the Istanbul initiative of 30 June 2001, which calls for dialogue with the GCC states to create a new regional balance in the Middle East as part of the broader alliance in the Middle East, was accepted by the State of Kuwait in 2005 and its participation in the initiative, Iran has shown strong opposition to the Istanbul initiative, accusing it of increasing foreign presence in the region (Baabood, 2014).

The continued renewal of Kuwait's security agreements with the United States of America is due to its inability as a small country in the region, as well as the inability of the GCC countries to formulate a common security policy (Baabood, 2014).

\section{Conclusion}

The Kuwaiti-Iranian relations during the period from 2003 to 2015 were positive in most of their stages, despite some tension. Kuwait was able to maintain normal relations in most periods with Iran, concluded several memorandums of understanding and agreements with Iran, and adopt policy of balance and strategic hedging, as it is a member of the Gulf Cooperation Council (GCC), which varies in its relations with Iran.

Security is one of the most important dilemmas for small countries. Therefore, since the liberation of Iraq from the Iraqi invasion and its signing of defense security agreements, Kuwait has been renewing these agreements because there is no effective security system, despite the presence of the Al-Jazeera Shield Forces. However, this force does not deter the external threat represented in Iran, which is militarily superior.

Three scenarios can be developed for the Kuwaiti-Iranian relations, which determine the nature of their relations in the future, namely, the stalemate in relations, which is often the predominant feature between Iran and Kuwait in the most prominent issues. These include opposing the Kuwaiti and Iranian visions of the foreign presence in the Gulf, the issue of the UAE islands and the issue of the continental shelf between Kuwait and Iran.

The second scenario in the Kuwaiti-Iranian relations is the compatibility between them and the cautious cooperation through the strategy of containment and engagement. Kuwait does not deal with Iran as a source of threat, and they involved in resolving bilateral disputes on one hand and through the GCC system on the other.

The other scenario is the tension between Kuwait and Iran. This tension is related to Iran's interference in Kuwait's domestic affairs and to the Shiite citizens whom Iran considers to be interfering in Kuwait's internal affairs, as well as the continued disclosure by the Kuwaiti government of espionage networks working for Iran as in the past years.

As for the future of the Gulf security, there must be a consensus between the Gulf States and Iran, since Gulf security is linked to the countries of the region, and security will be achieved only in the case of cooperation.

\section{References}

Abdullah, A. (2006). Gulf Regional System. UAE, Dubai: Gulf Research Center.

Abdul Rahman, S. (2007). Kuwaiti - Iranian relations serious stage and convergence cautious. Al-Jazeera Net.

Abu L. S. (2012, July). The role of the traditional and emerging middle states in the international system after the end of the Cold War. International Politics Journal, 189, 12.

Al Hamed, M. A. (1997). Gulf Security and its Implications for the GCC Countries. Emirates Center for Strategic Studies and Research. Lecture Series. UAE. No. 16. p.22.

Al-vefagh Online. (2014). Kuwait and Iran sign a number of bilateral agreements. http://www.al-vefagh.com/Search/Quick

Al-Alam Channel. (2015). Kuwait talks about the readiness of the Gulf countries to dialogue with Iran. http://www.alalam.ir/print/1746152

Al-Alam TV. (2014). Assistant Iranian Foreign Minister visits Kuwait. http://www.alalam.ir/news/1580858 
Alawi, Mustafa. (2005). Regional Security between National Security and International Security. Journal of Concepts of the Scientific Foundations of Knowledge, vol. 4, Cairo.

Al-Ebraheem, H. A. (1984). Kuwait and the Gulf: Small States and the International System, Kuwait University. p8.

Al-Hadrami, O. (2013). Small State, Capacity and Role Theory Approach, Al-Manarah, Volume 19 Issue 4. Amman.

Al-Hayat Newspaper. (2013). Kuwait Summit: Welcome to the nuclear agreement and condemnation of Hezbollah in Syria. http://www.jbcnews.net/article/35812

Al-Kibsi, A. (1997). Principles of Political Science (1st ed.). Institution of Textbook Press.

Al-Majalla Magazine. (1993). Reading in Foreign Policy, Issue 687.

Al-Mutairi, N. (2004). Contemporary Kuwaiti-Iranian Relations (pp. 163-164). Master Thesis, Faculty of Economics and Political Science, Cairo University.

Al-Watan newspaper. (2015). Kuwait refutes Tehran's allegations. http://alwatan.kuwait.tt/articledetails.aspx?id=448133

Cooper, A. F., Higgott, R. A., \& Nossal, K. R. (1993). Relocating Middle powers: Australia and Canada in Changing world order, Vancouver: UBC, Press.

Arabic CNN. (2014). Iran to export gas to Kuwait https://arabic.cnn.com/business/2014/05/05/iran-kuwait-trade

Azari, A., \& Akram, M. (2002). An overview to problems of subsurface drainage studies, and implementation in Iran. Iranian National Committee on Irrigation and Drainage (IRNCID).

Baabood, A. (2014). The Future Role of Major International Powers in Gulf Security, The Gulf in a Changing Strategic Context (1st ed.). Qatar, Doha: Al-Jazira Center for Studies.

Badri, M., \& Abdullah, J. (2014). Regional Developments and their Economic Implications for the Gulf States and Energy Security (1st ed.). The Gulf in a Changing Strategic Context. Aljazeera Center for Studies, p. 304.

Badri, H., \& Abdullah, J. (2014). Regional Developments and their Economic Implications for the Gulf States and Energy Security (1st ed.). The Gulf in a Changing Strategic Context, Research Group, Al Jazeera Center for Studies.

BBC News. (2015). Hajj stampede: At least 717 killed in Saudi Arabia. http://www.bbc.com/news/world-middle-east-34346449

Christie, R., \& Dewitt, D (2006). Middle power and regional security. Paper presented at the Universidad de san Andres Buenos Aires.

Ercomishvili, D. (2016). One for All, Each on Its Own: Analyzing the Post-Soviet System of Collective. Security journal of regional security. University of Belgrade/Faculty of Political Science.

Ezz Al-Arab, M. (2012, October). How Gulf Governments Deal with Shiite Demands. Cairo: Al-Ahram Strategic File.

Fars News Agency. (2014). The visit of the President of the Iranian Shura Council to Kuwait 2014. http://arabicfarsnews.com/print news/13931218001469

Fars News Agency. (2015). Amir of Kuwait Congratulates Leader and President on Nuclear Agreement. http://ar.farsnews.com/iran/news/13940504001424

Fars News Agency. (2015). Kuwaiti Foreign Minister: We must have a close relationship with Iran. http://en.farsnews.com/newstext.aspx?nn=13930312001333

Gresh, G. F. (2015). Gulf Security and the U.S. Military, Regime Survival and the Politics of Basing.

Gulf Center for Iranian Studies. (2011, August). Iranian-Kuwaiti Relations between Continuity and Change, Gulf Center for Iranian Studies.

Gulf Center for Iranian Studies. (2017). Expulsion of Iranian diplomats from Kuwait and the closure of cultural and military attaches.

Hamdan, M. (2014). Kuwait and Neighboring Countries (p. 143). Cairo: Al-Raya Center.

Hilal, R. (1991). The Struggle over Kuwait, the Issue of Security and Revolution (1st ed., p. 115). Cairo:Sinai Publishing. http://www.asharqalarabi.org.uk/barq/b-qiraat-1319.htm

Iran Arabic Radio. (2014). Iranian president calls on Amir of Kuwait to visit Tehran. http://arabic.irib.ir/component/k2/item/141322

Jones, P. (1998). Towards A Regional Security Regime of the Middle East: Issues and options. Stockholm International peace Research Institute. Canada. p.8.

Jordan, E. (2001). Conceptualising the Difference between Emerging and Traditional Middle powers. paper presented 
at the national conference of the south African Association of political studies, University of Durban Westville, South Africa.

Keohane, R. O. (1969, April). Lilliputians' Dilemmas: Small States in Internatinal Politics. International Organization, 23(2), 291-310.

KUNA. (2015). Explosion in Al-Sadiq Mosque in Kuwait City, Deaths and injuries. http://www.kuna.net.kw/ArticleDetails.aspx?id=2448467

KUNA. (2015). Kuwait hosts third donors' conference with wide international participation.http://www.kuna.net.kw/mobile/ArticleDetails.aspx?id=2433087

KUNA. (2016, December). Report on the most important local events for 2016. Kuwait News Agency (KUNA).

KUNA. (2017). Discrimination Abolishes the execution sentence of the accused in the case of the Al-Abdali terrorist group and makes him a permanent prisoner. http://www.kuna.net.kw/ArticleDetails.aspx?id=2619684\&language=ar

KUNA. (2017). Discrimination cancel the death sentence of the accused in the case of the terrorist group of Al-Abdali and makes him a permanent prisoner.http://www.kuna.net.kw/mobile/ArticleDetails.aspx?id=2619684

Kuwait News Agency (KUNA). (2014). Kuwait hosts third donor conference with wide international participation. http://www.kuna.net.kw/mobile/ArticleDetails.aspx?id=2433087

Kuwait Research and Studies Center. (2014).Kuwait Geography, Kuwait Research and Studies Center, Kuwait.

Maoz, Z. (2013). Regional Security in the Middle East: Past Present and Future. Routledge.

Morgenthau, H. (1972). Science: Servant or Master? New American Library.

Peterson, J. E. (1986). Defending Arabia. London: Croom Helm; New York: St. Martin's, press, p88.

Rabee, H. (1995). The Theory of Arab National Security and the Contemporary Development of International Cooperation in the Middle East. Cairo: Dar Al-Mawkif Al-Arabi.

Salem, A. F. (2017). Shiites in Kuwait: Citizenship is the solution. Eedaat Journal. https://www.ida2at.com/shiites-in-kuwait-citizenship-is-key

Shoma News. (2015). Iranian president's interview with Iranian state television. See: http://shomanews.com/fa/news/204247

Tabank news. (2014). Iranian exports to Kuwait. http://www.tabnak.ir/ar/news/25161

Tawfiq, S. (2012). Principles of International Relations. Amman: Dar Wael Publishing. pp. 92-96.

The Arab East Center for Civilizational and Strategic Studies. (2013) Donors Conference in Kuwait, one and half billion for the Syrian people. London

The Gulf Center for Iranian Studies. (2017, July). The expulsion of Iranian diplomats from Kuwait and the closure of the cultural and military complexes.

Thorhallsson, B. (2006). The Size of States in the European Union: Theoretical and Conceptual Perspectives. Journal of European Integration, 28(1), 7-31

Toumi, H. (2014). Kuwait and Iran: A Fluctuating History, Gulf news Iran.

Viorst, S. (1995, November). The limits of the revolution. Foreign Affairs, 74(6).

Zakaria, J. Security in the Arabian Gulf since the British withdrawal to the Second Gulf War. Emirates Center for Strategic Studies and Research, Lecture Series, UAE No. 11, pp. 3-4.

\section{Copyrights}

Copyright for this article is retained by the author(s), with first publication rights granted to the journal.

This is an open-access article distributed under the terms and conditions of the Creative Commons Attribution license (http://creativecommons.org/licenses/by/4.0/). 